\title{
СМЕРТНОСТЬ ПЕШЕХОДОВ В РОССИИ: УСТОЙЧИВОЕ СНИЖЕНИЕ В ТЕЧЕНИЕ 25 ЛЕТ?
}

\author{
АНАСТАСИЯ ПЬЯНКОВА, ТИМУР ФАТТАХОВ
}

\begin{abstract}
В исследовании с использованием широкого круга источников данных (HCoD, IRTAD, UNECE statistical database, данные МВД) показано, что существенное превышение смертности пешеходов над смертностью водителей и пассажиров по данным Российской базы данных по рождаемости и смертности (РосБРиС) в России в 1988-1999 г2. - аномальное явление. Поэтому для оченки уровня смертности по категориям участников дорожного движения правомернее доверять данным МВД. В соответствии с ними в России смертность пешеходов никогда не превышала смертность водителей и пассажиров, и ее устойчивое снижение началось с 2003, а не с 1993 г. В 2008 г. смертность пешеходов впервые опустилась ниже минимальных значений советского периода, тогда как смертность водителей и пассажиров после взлётов и падений достигла уровня начала 1970-х годов только в 2015-2017 г2.
\end{abstract}

Использование данных государственной статистики смертности можно рекомендовать при рассмотрении дифференциальной дорожно-транспортной смертности: по полу, возрасту и типу местности (город/село). В то же время оценивать различия в смертности в разрезе категорий участников дорожного движения на ее основе следует с осторожностью. При проведении ретроспективных исследований предпочтительно опираться на следующие базы данных: The Нитап Cause-of-Death Database (HСоD) с 1988 г., РосБРиС с 1970 по 1988 г. и после 1999 г.

Имеются основания предполагать, что сложности в анализе долгосрочных тенденций смертности по категориям участников дорожного движения на основе государственной статистики смертности могут возникать во всех постсоветских странах, где использовалась советская краткая номенклатура причин смерти. Помимо этого показано, что при анализе дорожнотранспортной смертности по категориям участников на основе агрегированных рубрик кратких листов причин смерти важно учитывать степень распространенности кода V89 «Несчастный случай, связанный с моторным или немоторным транспортнымм средством неуточненного вида».

Ключевые слова: смертность пешеходов, смертность водителей и пассажиров, категории участников дорожного движения, статистика смертности, данные МВД, ДТП.

\section{ВВЕДЕНИЕ}

Для разработки действенных мер в сфере безопасности дорожного движения необходимо понимание дифференциации дорожно-транспортной смертности по социальнодемографическим и другим характеристикам, в том числе и по категориям участников дорожного движения. Известно, что существует дифференциация доли погибших в ДТП пешеходов в общем числе погибших в зависимости от уровня экономического благосостояния стран (World Health Organization 2018; Yasin, Grivna, Abu-Zidan 2020): чем ниже ВВП на душу населения, тем выше доля пешеходов среди всех погибших в ДТП и выше уровень смертности пешеходов (Eid, Abu-Zidan 2015; Sengoelge, Laflamme, ElKhatib 2018).

АНАСТАСИЯ ИвАНОВНА ПьяНКОВА (apyankova@hse.ru), НАЦИОНАЛЬНЫЙ ИССЛЕДОВАТЕЛЬСКИЙ УНИВЕРСИТЕТ «ВЫСШАЯ ШКОЛА ЭКОНОМИКИ», РОсСия.

ТИМУР АСФАНОВИЧ ФАТТАХОВ (tfattahov@hse.ru), НАЦИОНАЛЬНЫЙ ИССЛЕДОВАТЕЛЬСКИЙ УНИВЕРСИТЕТ «ВЫСШАЯ ШКОЛА ЭКОНОМИКИ», РОССИЯ. ИССЛЕДОВАНИЕ ВЫПОЛНЕНО ПРИ ФИНАНСОВОЙ ПОДДЕРЖКЕ РФФИ В РАМКАХ НАУЧНОГО ПРОЕКТА №19-013-00060. СТАТЬЯ ПОСТУПИЛА В РЕДАКЦИЮ В СЕНТЯБРЕ 2020 Г. 
При обращении к данным Российской базы данных по рождаемости и смертности (далее РосБРиС) за 1965-1998 гг. и деперсонифициронным данным Росстата за 20002017 гг. кажется, что удалось достичь значительного прогресса в снижении смертности пешеходов после резкого подъема в конце 1980-х годов и соответствующего пика в начале 1990-х (рисунок 1). Уровень смертности пешеходов с 1993 г. снизился в 5 раз и составил 3,2 умерших на 100 тыс. человек в 2017 г. Смертность водителей и пассажиров не испытала столь резких взлетов и падений до конца 1990-х годов.

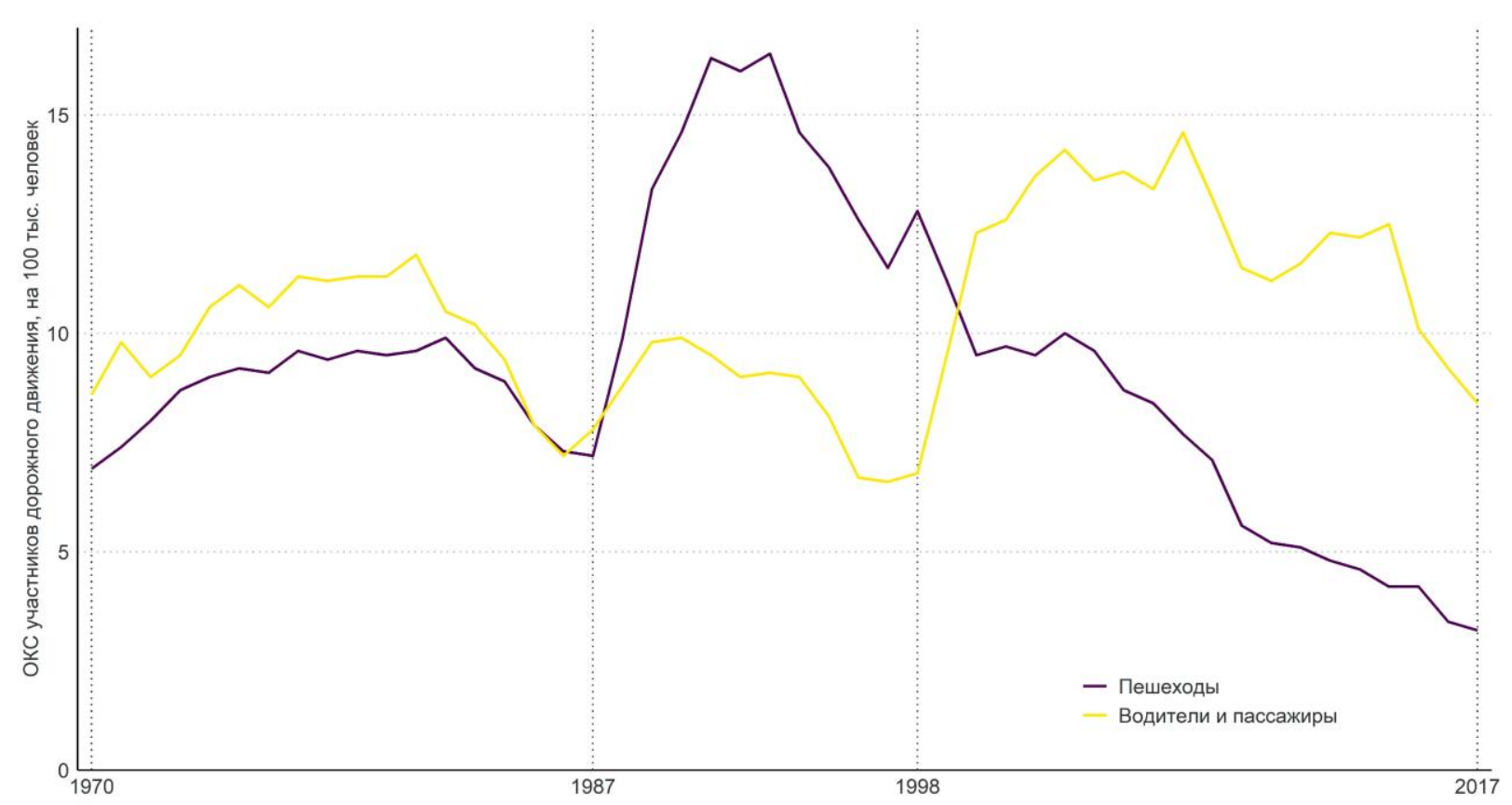

Рисунок 1. Смертность основных участников дорожного движения в России, 1970-2017

Примечание: ОКС - общчй коэффищиент смертности.

Источник: данные РосБРиС и Росстата.

Динамика смертности пешеходов в разрезе пола, городской и сельской местности свидетельствует о тех же тенденциях (рисунок 2). Коэффициент смертности среди мужчинпешеходов в городской местности снизился в 6 раз (с 26 до 4 умерших на 100 тыс. человек за 1993-2017 гг.), в сельской местности - в 4 раза за аналогичный период. Для женщинпешеходов соответствующие коэффициенты снизились в 4 и 3 раза. Те же тенденции характерны и для всех возрастных групп.

Столь устойчивое и длительное снижение смертности пешеходов как в целом, так и по более подробным категориям участников дорожного движения вызвало у нас ряд вопросов.

Возможно ли в принципе, чтобы смертность пешеходов в течение достаточно длительного времени превышала смертность водителей и пассажиров, как это отмечалось в конце 1980-х и 1990-х годах в России по данным РосБРиС (рисунки 1 и 2)? Это противоречит результатам систематических обзоров по данной проблематике, свидетельствующих, что доля погибших пешеходов сильно варьировалась по регионам 
мира, выделяемых ВО3, однако превышала 50\% от всех погибших только в странах Африки. При этом в среднем по странам с низким, средним и высоким уровнем благосостояния доля погибших пешеходов составляла 45, 30 и 20\% соответственно (Charters, Gabbe, Mitra 2017; Naci, Chisholm, Baker 2009).
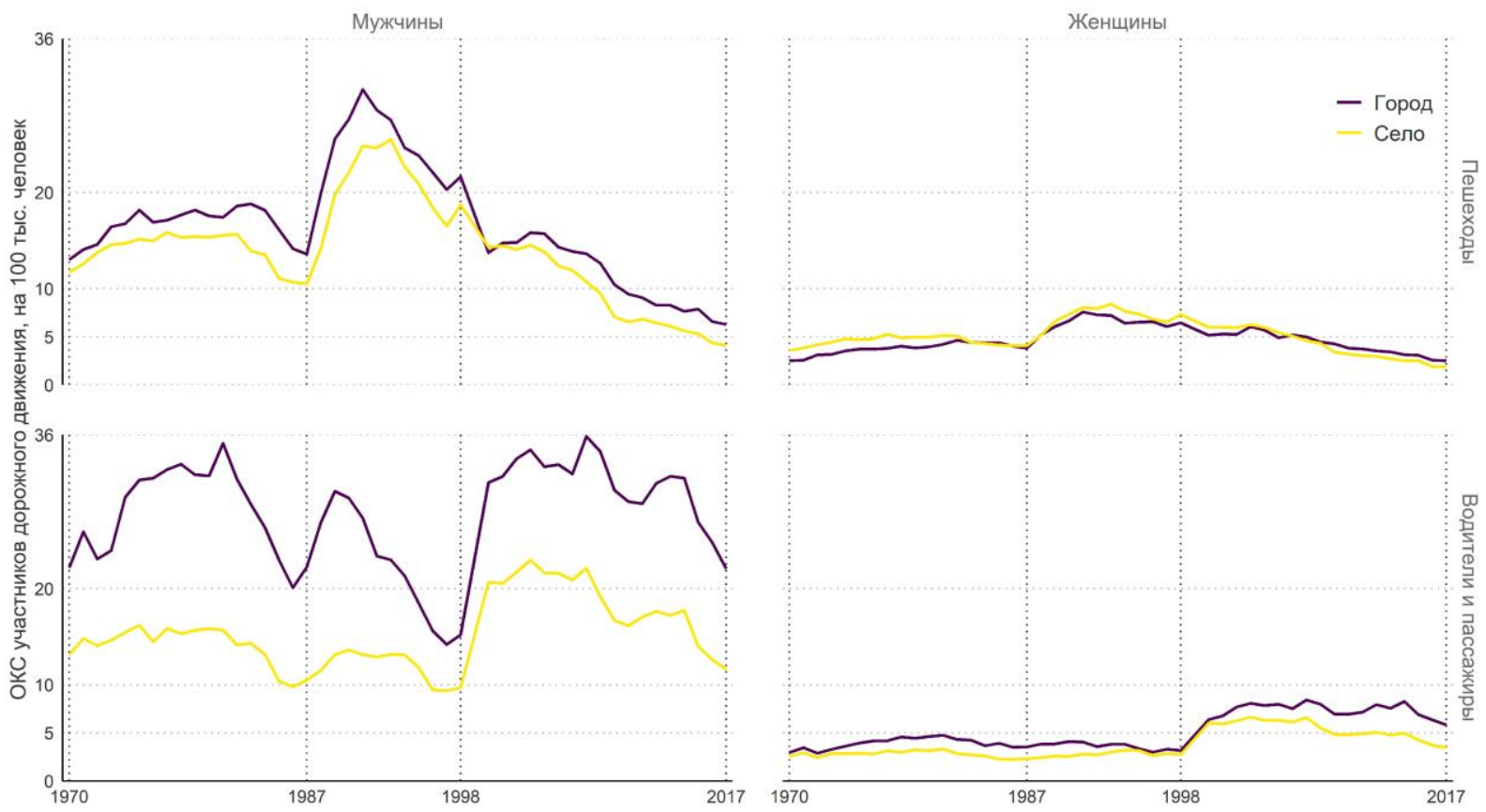

Рисунок 2. Дифференциация дорожно-транспортной смертности в России, 1970-2017

Источник: данные РосБРиС и Росстата.

Почему не отмечается второго пика смертности пешеходов в конце 1990 -х - начале 2000-х годов? Второй пик смертности был характерен как для водителей и пассажиров, так и большинства внешних причин смерти (Вишневский 2017).

Чем объясняется столь небольшой рост смертности водителей и пассажиров после отмены антиалкогольной кампании и столь резкий ее рост в 1999 году? С одной стороны, это не соответствует динамике смертности от внешних причин смерти в России в этот период. С другой - противоречит фиксируемой полицией более рискованной форме поведения водителей, нежели пешеходов в конце 1980-х годов. Так, в статистических сборниках МВД отмечается, что в 1989 г. в СССР «из всех водителей, по вине которых возникли ДТП, 39,8\% не имели права на управление соответствующей категорией транспортного средства, 22,1\% находились в нетрезвом состоянии. Нетрезвым был также каждый пятый виновных в ДТП пешеход» (Преступность и правонарушения... 1990).

Насколько возможна асинхронность динамики смертности пешеходов и водителей и пассажиров, наблюдаемая в конце 1990-х и до середины 2000-х годов, когда смертность водителей и пассажиров интенсивно росла, а пешеходов продолжала снижаться? Смертность основных категорий участников дорожного движения все же взаимосвязана, так как поведение водителей во многом определяет смертность пешеходов, поэтому, если резко растет смертность водителей, то это должно было бы в какой-то степени отразиться на смертности пешеходов. 
Эти вопросы определили цель нашего исследования - понять, чем обусловлено существенное превышение смертности пешеходов над смертностью водителей и пассажиров в России по данным РосБРиС в конце 1980-х и начале 1990-х годов, и верифицировать данный источник данных, сопоставляя его с другими как доступными, так и малодоступными источниками данных о дорожно-транспортной смертности в России и других странах. В связи с этим основной задачей было восстановление структуры погибших в ДТП по категориям участников дорожного движения по данным советской, а затем и российской статистики МВД за аналогичный период.

\section{ДАННЫЕ И МЕТОДЫ}

В рамках системы отчетности МВД выделены следующие категории участников дорожного движения: 1) пешеходы и велосипедисты; 2) водители и пассажиры. Сведения об общем числе погибших в ДТП, в том числе по категориям участников дорожного движения, по данным российского МВД и данным дорожной полиции в других странах ${ }^{1}$ были получены:

- по СССР, России, Латвии, Молдавии за 1970-1989 гг. из статистических отчетов, регулярно выпускавшихся Научно-исследовательским центром по безопасности дорожного движения МВД СССР (НИЦ по БДД... n.d.);

- по России за 1990-1991 гг. из статистических сборников «Преступность и правонарушения»;

- по России за 1993-2004 гг. и по всем остальным постсоветским странам за 19932018 гг. из статистической базы ЕЭК ООН (UNECE Statistical Database 2020);

- по России за 2005-2014 гг. из коллективной монографии (Вишневский 2017); с 2015 г. соответствующие данные МВД доступны онлайн ${ }^{2}$;

- по ряду стран Европы, США, Южной Кореи за 1970-2010 гг. из International Road Traffic and Accident Database (IRTAD), которые получены в 2012 г., когда был открыт бесплатный доступ к данному источнику данных. В настоящее время бесплатный доступ к данным IRTAD о числе погибших по категориям участников дорожного движения закрыт.

В случае если в России, Латвии, Молдавии за какой-либо год из 1970-1989 гг. отсутствовали данные, характеризующие структуру погибших по категориям участников дорожного движения, мы ее принимали аналогичной структуре погибших в СССР в этом году, которая была восстановлена за каждый год. В этом случае абсолютные числа погибших по категориям участников были получены, исходя из абсолютного числа погибших в данной стране в данном году и структуры погибших в СССР в том же году. Помимо этого, отсутствие данных о возрастной структуре погибших в ДТП по данным МВД не позволило рассчитать стандартизованные коэффициенты смертности, поэтому мы

\footnotetext{
${ }^{1}$ В разные исторические периоды в России подразделение МВД, ответственное за безопасность дорожного движения, носило разные официальные названия. В настоящий момент за статистику дорожно-транспортных происшествий отвечает ГИБДД МВД РФ. Этот орган по своим функциям вполне соответствует обобщенному понятию «дорожная полиция», которое мы используем применительно к другим странам, не вдаваясь в национальные особенности ее ведомственной подчиненности.

${ }^{2}$ URL: http://stat.gibdd.ru/
} 
анализировали общие коэффициенты смертности в разрезе участников дорожного движения.

Мы воспользовались возрастными коэффициентами смертности за период с 1970 по 1999 г., размещенными в базе данных РосБРиС ЦДИ РЭШ, аккумулирующей российские данные государственной статистики смертности. Сумма умерших по рубрикам №№160 и 161 краткой номенклатуры причин смерти пересмотра 1988 г. рассматривалась как погибшие в ДТП («motor vehicle traffic accidents»). Погибшие по рубрике №160 рассматривались как водители и пассажиры, по №161 - как пешеходы и велосипедисты. Далее с 2000 по 2017 г. использовалось понятие погибшего в «motor vehicle traffic accidents» и были агрегированы соответствующие ей трехзначные коды причин смерти МКБ-10 (V02V04, V09, V12-V14, V20-V79, V82-V87, V89). В качестве пешеходов и велосипедистов рассматриваются умершие, закодированные кодами причин смерти V02-V04, V09, V12V14. Водители и пассажиры были определены как умершие и закодированные кодами V20V79, V82-V87, V89.

Для сравнения России с другими постсоветскими странами мы использовали общие коэффициенты смертности из The Human Cause-of-Death Database (HCoD). Для России число погибших пешеходов определялось как сумма погибших по следующим рубрикам из широкого списка рубрик краткой номенклатуры 2006 г.: 1) 239. Pedestrian injured in transport accident; 2) 272. Pedestrian injured in collision with motor vehicle, nontraffic accident. Для Эстонии, Латвии, Литвы, Молдавии числу погибших пешеходов соответствовала рубрика №196 «Pedestrian injured in collision with motor vehicle» (коды V02-V04, V09) из сокращенного листа причин смерти по этим странам, представленного в описании данных на сайте HCoD. Число погибших водителей и пассажиров в России определялось как сумма умерших по следующим рубрикам: 1) 240. Car occupant injured in transport accident; 2) 241. Occupant of other transport vehicle in transport accident; 3) 273. Other persons injured in collision with motor vehicle, nontraffic accident. Для Эстонии, Латвии, Литвы, Молдавии контингенту погибших водителей и пассажиров соответствовала рубрика №195 «Transport accident with motor vehicle» (коды V12-V14, V19, V20-V79, V82, V87) из сокращенного листа причин смерти по этим странам.

Категория погибших пешеходов в этих странах полностью аналогична по составу кодов МКБ-10 (V02-V04, V09) сумме российских двух рубрик (№№239 и 272). Невключение Белорусии и Украины объясняется другим составом рубрик, с помощью которых можно выделить пешеходов. В этих странах он шире (V01-V09), и туда попадает относительно большой код по числу умерших - V05 (Пешеход, пострадавший при столкновении с поездом или другим железнодорожным транспортным средством).

Состав рубрики №195 «Transport accident with motor vehicle» (коды V12-V14, V19, V20-V79, V82, V87) не полностью сопоставим с суммой российских рубрик №№240-241 и 273 , с помощью которых можно выделить водителей и пассажиров. В России в эти рубрики включены полностью коды V84-86, V88 и частично V80-81, V83, V89. Однако это незначительно отразилось на уровне смертности российских водителей пассажиров по данным HCoD, так как число умерших, закодированных этими кодами, невелико. В 2014 г. 
оно составило 614 человек или 3,3\% от числа умерших водителей и пассажиров (от суммы умерших по рубрикам №№240, 241, 273).

\section{РезУЛьтаты}

\section{Смертность участников дорожного движения в России по данным государственной статистики смертности и МВД}

В России общие коэффициенты смертности от ДТП по данным государственной статистики смертности и МВД на протяжении длительного времени не имели существенных расхождений (см. рисунок 3 в (Pyankova, Fattakhov 2020)). Расхождения числа умерших и соответственно общих коэффициентов смертности по данным МВД и государственной статистики смертности находятся в русле аналогичных показателей, фиксируемых в других странах (см. Приложение 1 в (Пьянкова и др. 2019).

Чтобы ответить на поставленные вопросы относительно динамики смертности пешеходов и водителей и пассажиров по данным государственной статистики смертности, мы решили сначала оценить, насколько они применимы к аналогичным показателям, рассчитанным по данным МВД.

Данные МВД свидетельствуют о следующем (рисунок 3). Во-первых, смертность пешеходов и велосипедистов никогда не превышала смертность водителей и пассажиров, в отличие от аналогичных показателей, рассчитанных на основе данных РосБРиС. Во-вторых, второй пик смертности пешеходов и велосипедистов в конце 1990-х - начале 2000-х годов отмечался так же, как для водителей и пассажиров и большинства внешних причин смерти. В-третьих, рост смертности водителей и пассажиров после отмены антиалкогольной кампании был резким, общий коэффициент смертности (ОКС) за 4 года с 1987 по 1991 г. почти удвоился, достигнув в 1991 г. максимального когда-либо фиксируемого значения. Вторая волна роста смертности водителей и пассажиров пришлась на период 2000-2007 гг., и была более сглаженной. В-четвертых, изменения смертности пешеходов и велосипедистов и водителей и пассажиров на протяжении всего периода наблюдения согласованы: росту смертности водителей и пассажиров соответствует рост смертности пешеходов и велосипедистов, в том числе в 1998-2002 гг. Устойчивое снижение смертности пешеходов и велосипедистов началось с 2003 г., определив начало снижения дорожно-транспортной смертности в России в целом. Снижению смертности пешеходов в 2003-2014 гг. соответствовало колебание смертности водителей и пассажиров на достаточно высоком уровне от 12 до 14 умерших на 100 тыс. человек. После 2014 г. началось снижение смертности водителей и пассажиров, что в совокупности с продолжающимся нисходящим трендом среди пешеходов и велосипедистов усилило снижение общей дорожно-транспортной смертности в России.

В итоге динамика смертности основных категорий участников дорожного движения по данным МВД отличается от аналогичных показателей по данным РосБРиС. Особенностей динамики коэффициентов, возникших при анализе рисунка 1 и выразившихся в вопросах исследования, не отмечается. 


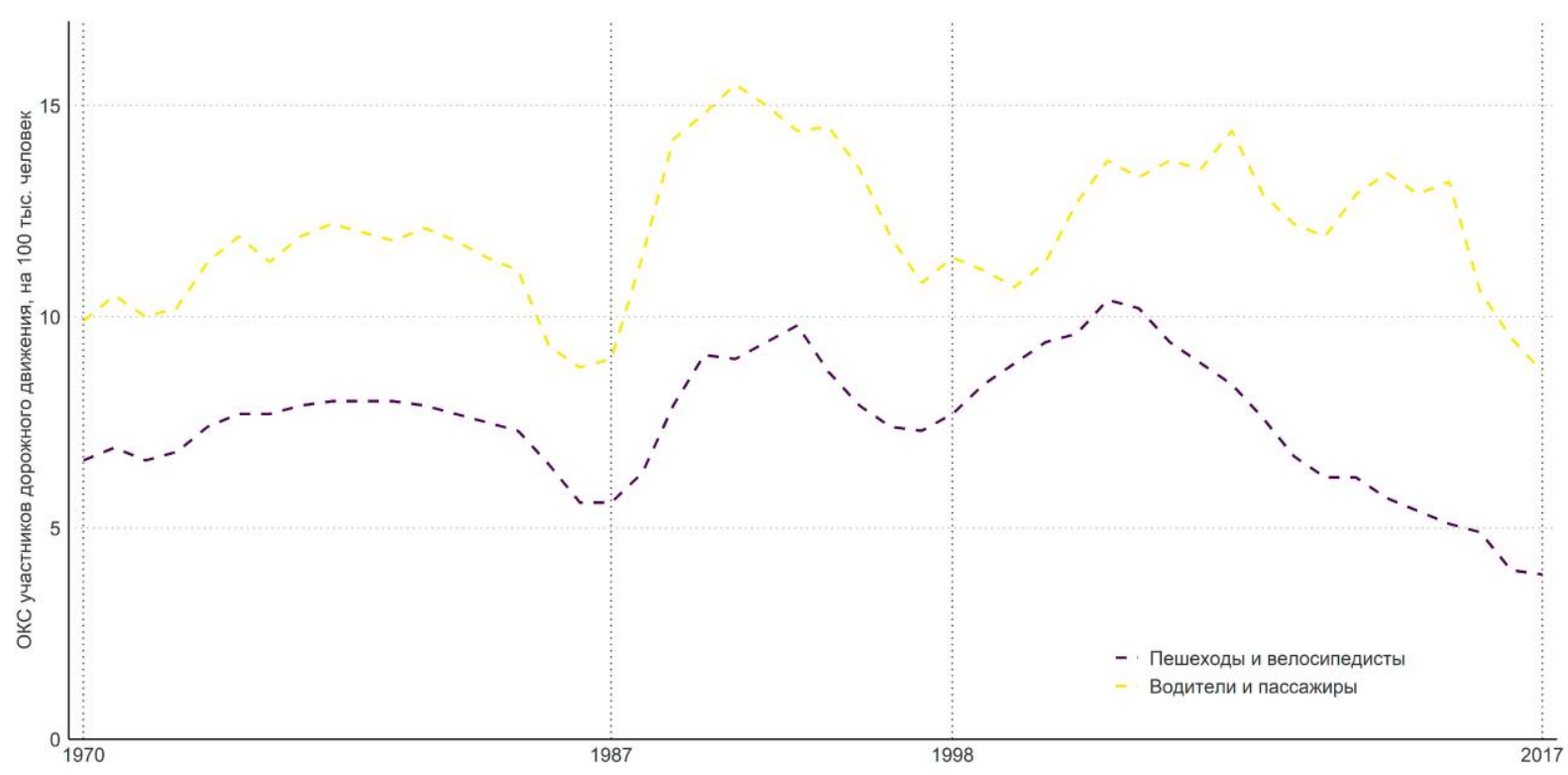

Рисунок 3. Смертность основных категорий участников дорожного движения в России, 1970-2017

Источник: данные МВД.

Сравнивая коэффициенты по данным МВД и государственной статистики смертности, можно сказать следующее. Смертность обоих категорий участников дорожного движения по данным полиции, несколько отличаясь по уровню, ведет себя синхронно аналогичным показателям, рассчитанным на основе государственной статистики смертности до 1988 г. Затем начинает прослеживаться несогласованность их динамики. По данным РосБРиС ОКС пешеходов увеличивается с 7 до 16 умерших на 100 тыс. человек с 1987 по 1991 г. По данным МВД подобного подъема смертности пешеходов и велосипедистов не отмечается (ОКС пешеходов и велосипедистов в вырос с 5,6 до 9 умерших на 100 тыс. человек за аналогичный период). Относительно роста ОКС водителей и пассажиров ситуация противоположная: резкий рост по данным МВД (с 9 до 15,5 умерших на 100 тыс. человек с 1987 по 1991 г.) и слабовыраженный по данным государственной статистики смертности (с 7,8 до 9,5 умерших соответственно), который не превысил максимального значения советского периода (11,8 мерших пешеходов на 100 тыс. человек в 1981 г.). Далее на протяжении действия краткой номенклатуры причин смерти пересмотра 1988 г. ОКС пешеходов превышает ОКС водителей и пассажиров по данным государственной статистики смертности, что сохраняется вплоть до перехода на МКБ-10. С 2000 г. смертность водителей и пассажиров вновь становится выше смертности пешеходов и велосипедистов по данным государственной статистики смертности, ее изменения синхронизируются с изменениями аналогичных показателей по данным МВД.

Таким образом, в России общий уровень дорожно-транспортной смертности по двум источникам данных согласуется, но этого нельзя сказать о ее динамике по категориям участников дорожного движения. Максимальное рассогласование данных приходится на промежуток 1988-1998 гг.

Отношение коэффициентов смертности пешеходов к соответствующим коэффициентам водителей и пассажиров по данным государственной статистики 
смертности еще более ярко свидетельствует об аномальности периода 1988-1999 гг. (рисунок 4). Видно, что для обоих полов вне зависимости от типа местности ОКС пешеходов выше соответствующих показателей водителей и пассажиров именно в период 1988-1999 гг. (красная заливка на рисунке 4, отношение больше 1). Однако до 1988 г. и после 1999 г. смертность пешеходов в основном ниже или сопоставима со смертностью водителей и пассажиров (рисунок 4, зеленая заливка, отношение меньше 1). Исключение составляет период 1970-1988 гг., когда уровень смертность женщин-пешеходов в сельской местности превышал уровень смертности женщин-водителей и пассажиров в среднем в 1,61,7 раза. Однако после 1988 г. отношение коэффициентов для этой категории также резко выросло (до 2,5-3 раз).
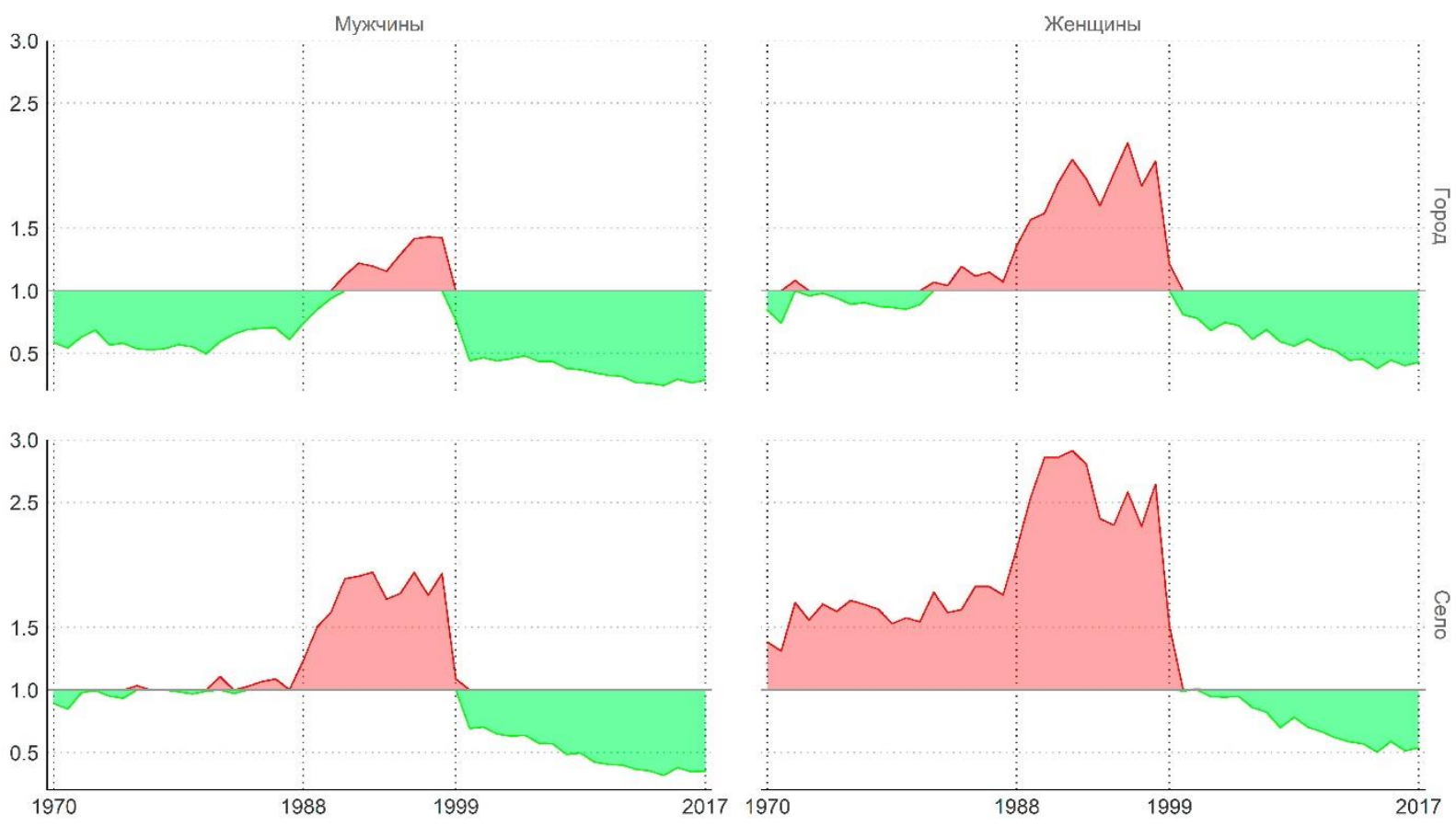

\section{Рисунок 4. Отношение ОКС пешеходов к ОКС водителей и пассажиров по полу и типу местности в России в разные исторические периоды по данным государственной статистики смертности}

В целом подобные флуктуации коэффициентов смертности основных категорий участников дорожного движения необычны, так как не согласуются с предшествующим и последующим периодами наблюдения.

Период 1988-1999 гг. ознаменован двумя событиями. Первое - это введение в 1988 г. новой версии советской краткой номенклатуры причин смерти, где было отменено деление несчастных случае, в том числе транспортных, на связанные и не связанные с производством (Mesle et al. 1996). Русские названия рубрик в краткой номенклатуре 1988 г., вместе составляющие весь блок несчастных случаев, связанных с транспортом (блок Е47 “Transport accidents" в МКБ-9), крайне необычны: 1) Несчастные случаи, связанные с мототранспортом (160); 2) Автомототранспортный несчастный случай на общественной дороге в результате наезда на пешехода (161); 3) Автомототранспортный несчастный случай (162). Необычность заключается в том, что в их названиях в качестве видов 
транспорта фигурируют только автомототранспорт и мототранспорт, а других видов транспорта нет (например, железнодорожного, воздушного или водного). Понять по названию, чем рубрика 160 отличается от рубрики 162, на наш взгляд, сложно. Второе - это переход на МКБ-10 и введение соответствующей российской краткой номенклатуры причин смерти. Переход на МКБ-10 произошел в совокупности с изменением системы кодирования причин смерти в медицинском свидетельстве о смерти, что подробно описано в других исследованиях (Danilova et al. 2016). Представляется обоснованным предположение, что именно эти два события обусловливают особенность существенного превышения смертности пешеходов над смертностью водителей и пассажиров, отмечаемую в этот период.

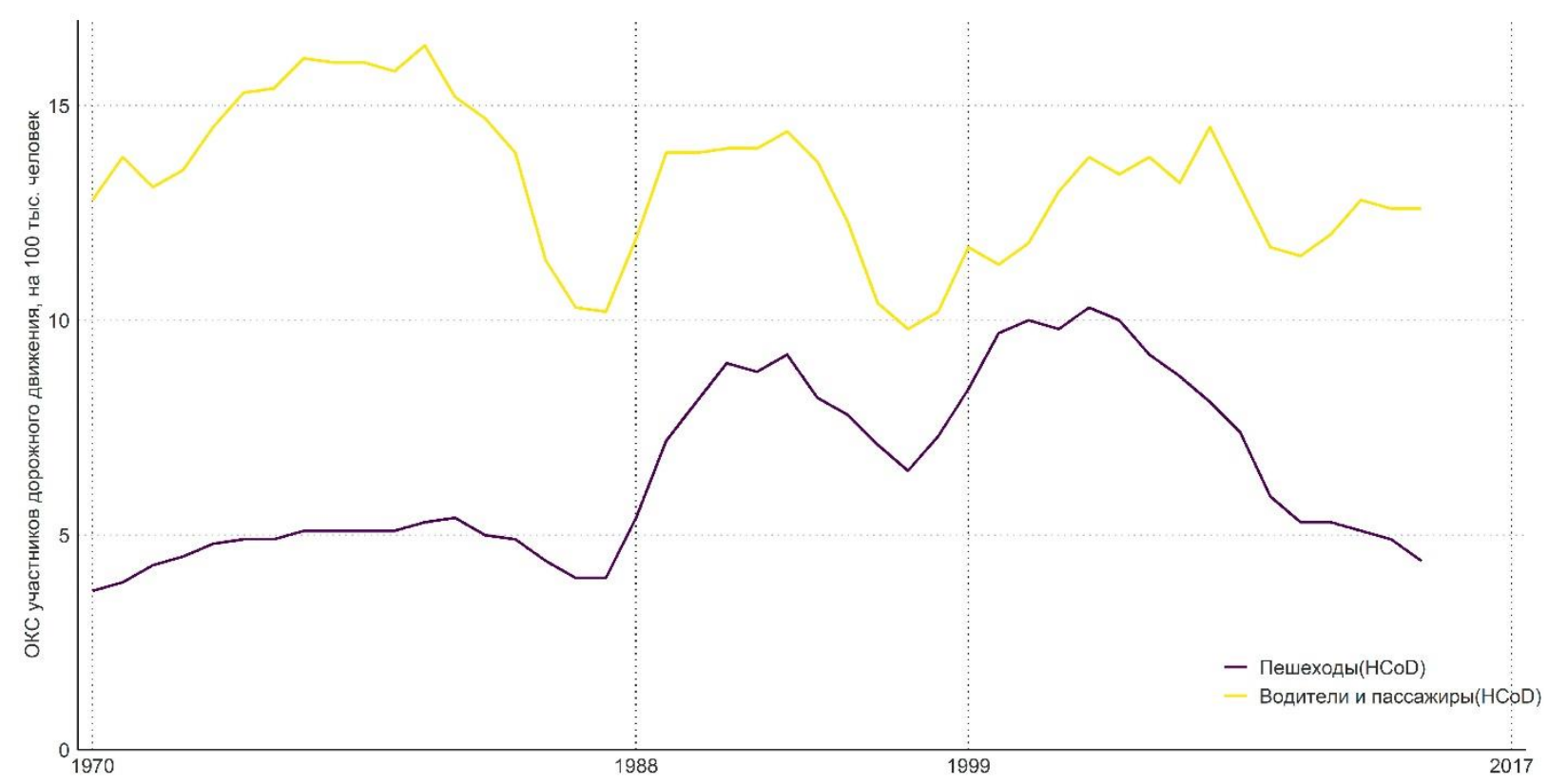

Рисунок 5. Смертность основных категорий участников дорожного движения в России, 1970-2014

Источник: данные $H C o D$.

Для устранения влияния изменений кратких классификаций причин смерти мы воспользовались международной базой данных по причинам смерти (HCoD). Для России она позволяет построить длинные ряды данных по причинам смерти в соответствие с одной и той же классификацией - российской краткой номенклатурой причин смерти пересмотра 2006 г. В соответствии с выделенными категориями участников дорожного движения (см. раздел «Данные и методы») видно, что общий коэффициент смертности пешеходов, так же, как и по данным МВД, никогда не превышал соответствующий коэффициент для водителей и пассажиров (рисунок 5). Отмечается второй пик смертности пешеходов в конце 1990-х - начале 2000-х годов, как и для водителей и пассажиров, хотя он выше предыдущего пика начала 1990-х годов. Изменения коэффициентов синхронны. Некоторые вопросы вызывает уровень ОКС обоих участников дорожного движения до 1988 г., но после этого года они сопоставимы с данными МВД в большей степени, чем данные РосБРиС. 


\section{Смертность пешеходов и водителей и пассажиров в некоторых постсоветских странах: данные государственной статистики смертности и дорожнной полиции}

Для международного сравнения из $\mathrm{HCoD}$ был выбран ряд постсоветских стран (Молдавия, Эстония, Латвия и Литва) с сопоставимыми рубриками (по составу кодов причин смерти МКБ-10), с помощью которых можно выделить участников дорожного движения. Картина дорожно-транспортной смертности по категориям участников в этих странах довольно противоречивая (рисунок 6). С одной стороны, в Эстонии и Литве ОКС водителей и пассажиров в основном выше смертности пешеходов, как и в России по данным HCoD и МВД. С другой стороны, в Латвии это справедливо лишь с 1996 г., тогда как до 1996 г. смертность пешеходов выше смертности водителей. Перелом приходится на год перехода страны с последней советской краткой советской номенклатуры причин смерти на МКБ-10, что произошло без промежуточного и краткого по времени перехода на МКБ-9, как это было в Эстонии и Литве.

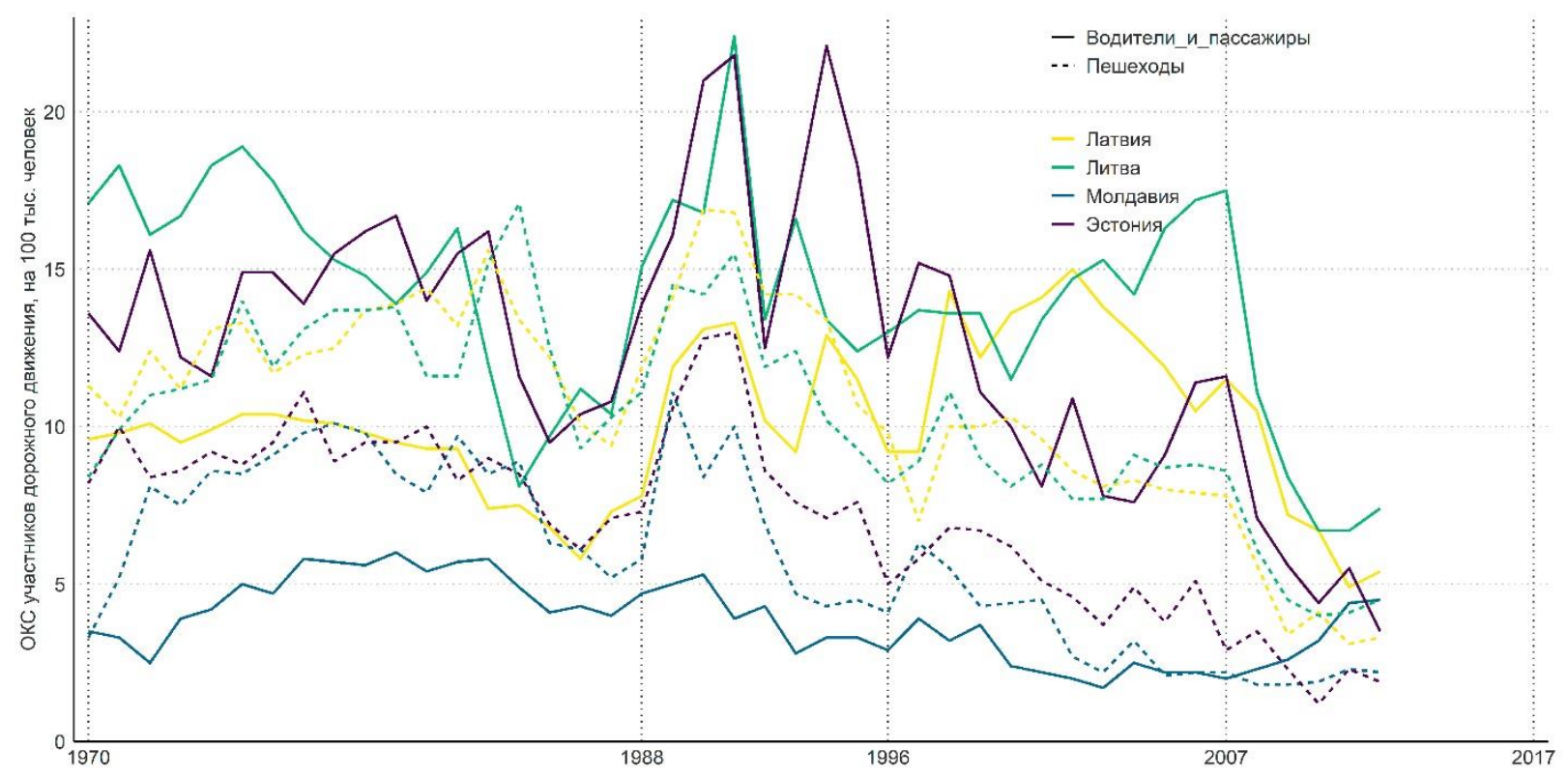

\section{Рисунок 6. ОКС основных категорий участников дорожного движения в ряде постсоветских стран, 1970-2014}

Источник: данные HCoD.

Еще более удивительная ситуация в Молдавии, где смертность пешеходов вплоть до 2006-2007 гг. выше смертности водителей и пассажиров. Однако категоризации участников дорожного движения в рамках текущей статистики смертности в Молдавии сложно доверять по причине кодирования большей части погибших в ДТП кодом V89 «Несчастный случай, связанный с моторным или немоторным транспортным средством неуточненного вида». В 2015 г. в Молдавии по данным The WHO Mortality Data Base этим кодом было закодировано 58\% погибших в ДТП (из кодов V02-04, V12-14, V19, V20-79, V82-87, V89). Тогда как в прибалтийских странах этот код либо вообще не использовался (Латвия, Эстония), либо число закодированных им умерших незначительно (Литва). 


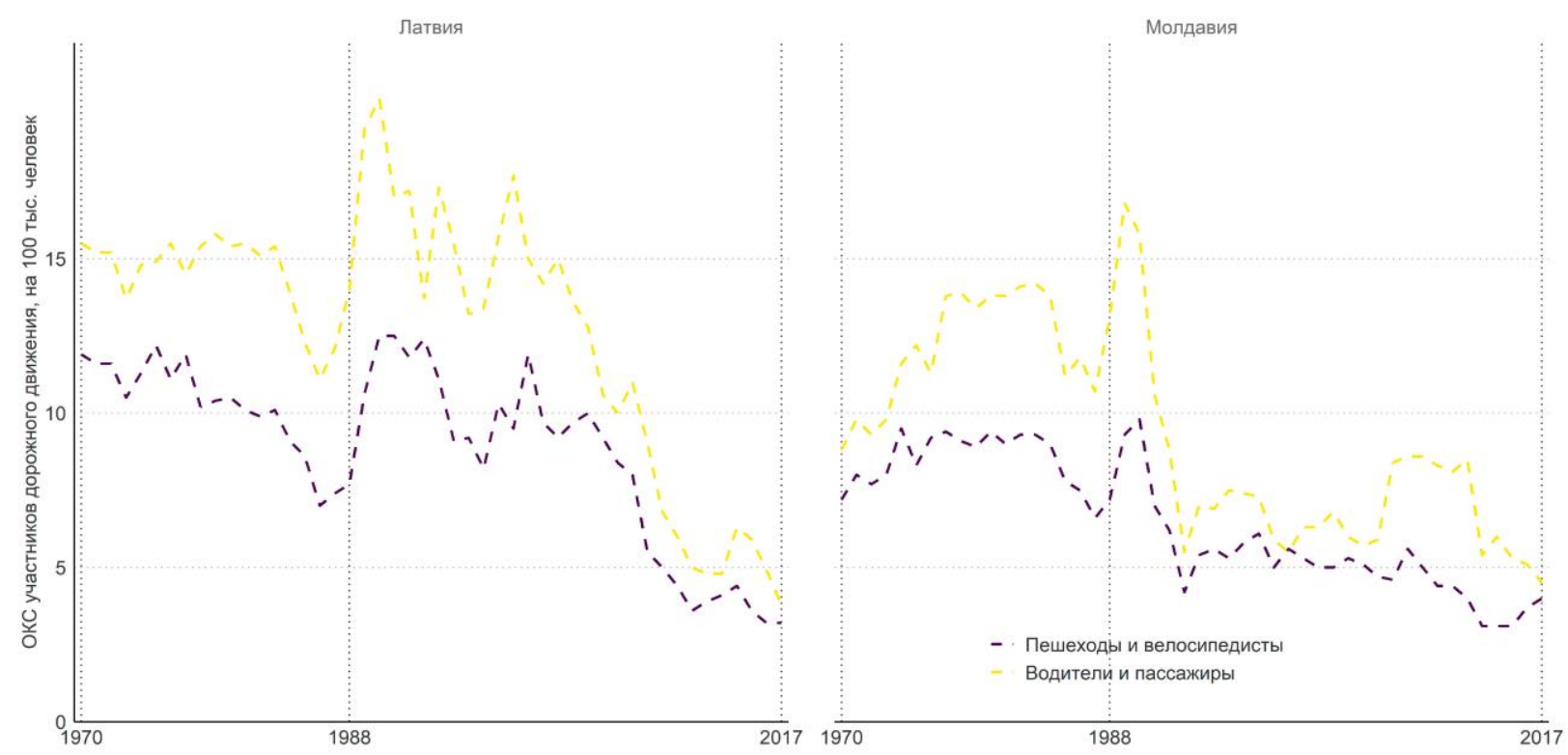

Рисунок 7. ОКС категорий участников дорожного движения в ДТП в Латвии и Молдавии, 1970-2018

Источник: данные дорожной полищии соответствующих стран.

Столь разное поведение основных категорий участников дорожного движения в похожих (географически, исторически, социально-экономически) странах, причем резко меняющееся на обратное в какие-то периоды, вызывает вопросы. Поэтому мы обратились, так же, как и по России, к данным дорожной полиции Латвии и Молдавии, чтобы оценить, насколько тенденции, полученные на их основе, соответствуют трендам, полученным на основе HCoD (рисунок 7). Результаты оказались такими же, как и по России, главный из них - смертность пешеходов в этих странах не превышала смертности водителей и пассажиров по данным полиции. Резкое падение ОКС обоих участников дорожного движения в Молдавии в 1994 г. объясняется публикацией данных в статистической базе ЕЭК ООН без данных по Приднестровью.

\section{Доля погибших пешеходов в общем числе погибших в ДТП:}

\section{Россия на фоне других стран}

В России доля погибших пешеходов и велосипедистов в общем числе погибших в ДТП по данным МВД в 1993-2018 гг. составляла в среднем 38\%. Для проверки, насколько их доля в общей структуре погибших по данным российской МВД соответствует показателям в других странах, мы обратились к международным базам данных, где основным источником информации являются данные дорожной полиции.

По данным статистической базы ЕЭК ООН, доля пешеходов среди всех погибших в ДТП на всем постсоветском пространстве сильно варьируется как между странами, так и внутри каждой страны в 1993-2018 гг., лишь в отдельные годы в ряде стран Закавказья (Азербайджан, Армения) и Средней Азии (Таджикистан, Туркменистан, Киргизия) незначительно превышает 50\% от всех погибших в ДТП (рисунок 8а). Именно для этих 
стран характерно наибольшее отклонение доли погибших пешеходов в большую сторону от средней по всем постсоветским странам (38,5\%) в 1993-2018 гг. Это значит, что рассчитанный на их основе ОКС пешеходов почти никогда в постсоветских странах в 1993-2018 гг. не превышал ОКС водителей и пассажиров по данным дорожной полиции.
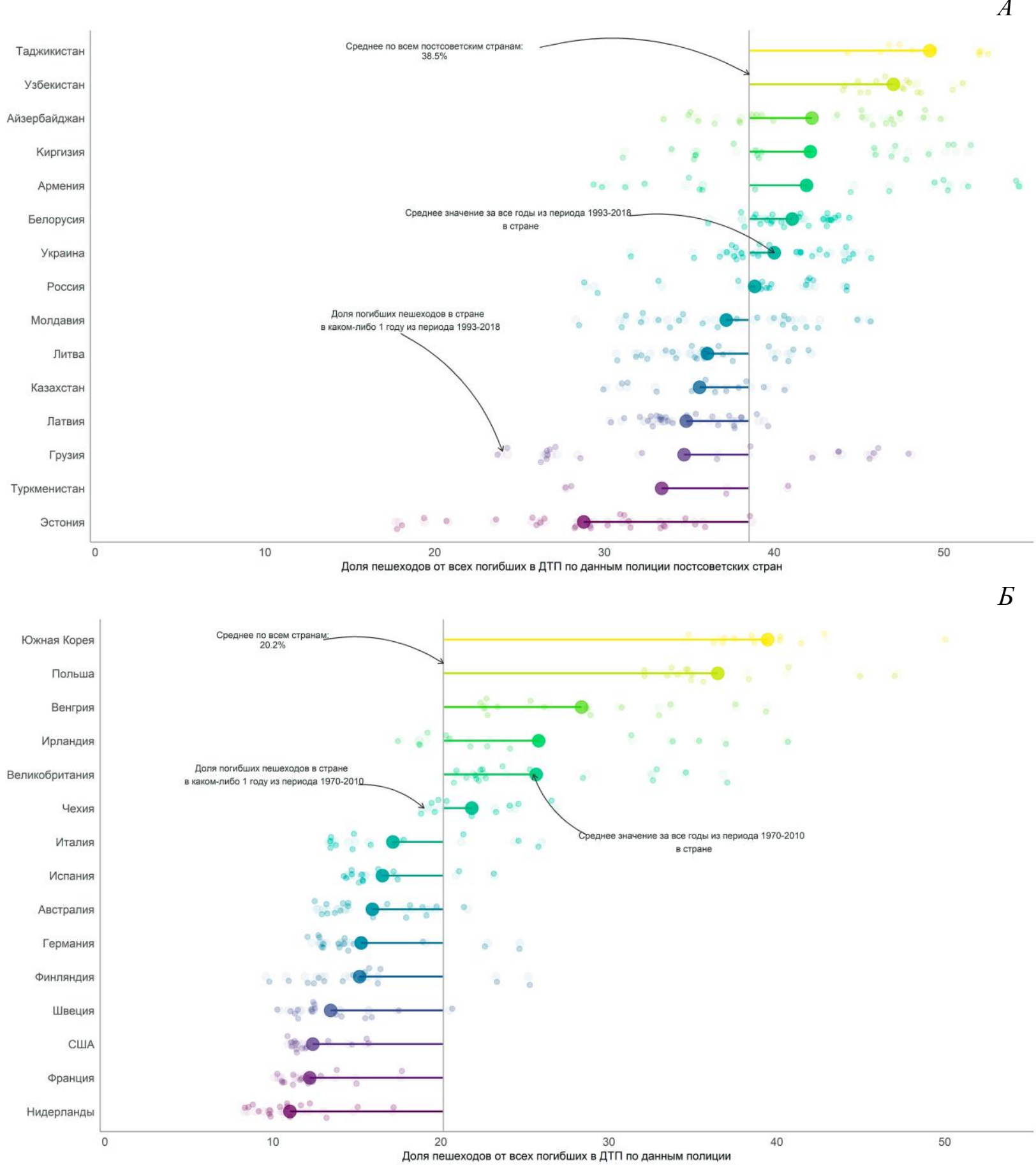

Рисунок 8. Доля погибших пешеходов от всех погибших в ДТП в постсоветских странах в 1993-2018 (а) и других странах мира в 1970-2010 (б), данные дорожной полиции, \%

Источник: A - данные UNECE Statistical Database, Б - данные IRTAD. 
Если сравнивать с другими зарубежными странами, по которым в статистической базе IRTAD был представлен более менее непрерывный ряд данных, то видно, что в них доля пешеходов погибающих в ДТП в период 1970-2010 гг. существенно ниже (рисунок 8б), чем в постсоветских странах в 1993-2018 гг. Наиболее близкой по этому показателю к постсоветским странам является Польша, где доля погибающих в ДТП пешеходов была очень высока в 1970 г. (47\%) и снизилась всего до 32\% к 2009 г. Некоторое исключение составляет и Южная Корея, где в первой половине 1990-х годов доля погибших в ДТП пешеходов приблизилась к 50\%, после чего она начала устойчиво снижаться. Однако она снизилась всего в 1,5 раза за 1990-2010 гг., против 3,2 раза в России за аналогичный период, если оценивать динамику по данным государственной статистики смертности (рисунок 1). В других странах (рисунок 8б) доля погибающих в ДТП пешеходов также снижалась в период 1990-2010 гг., однако снижение не превысило полутора раз ни в одной стране.

Ни в постсоветских странах, ни в странах Европы, США и Южной Кореи доля пешеходов устойчиво не превышала $50 \%$ от общего числа погибших в ДТП по данным дорожной полиции, за исключением некоторых отдельных лет в отдельных странах, когда этот показатель лишь приближался к этой отметке. Поэтому можно сказать, что данные МВД находятся в русле аналогичных показателей других странах.

\section{ОБСУЖДЕНИЕ}

С использованием разных источников данных, в том числе основанных на разных системах регистрации событий, было показано, что существенное превышение смертности пешеходов над смертностью водителей и пассажиров в России в 1988-1999 гг. по данным РосБРиС - аномальное явление. Возможно, это объясняется особенностями используемых классификаций, в соответствии с которыми представлены данные. Мы полагаем, что превышения смертности пешеходов над смертностью водителей в течение 10 лет с 1988 по 1999 г. не было, что подтверждается данными как МВД, так и других стран, а также непосредственно данным государственной статистики смертности, но представленными в единой классификации причин смерти в $\mathrm{HCoD}$.

Отсюда также следует, что смертность пешеходов скорей всего неуклонно снижается не с 1991-1993 гг., а с 2003 г., опустившись уже значительно ниже минимальных значений советского периода. Смертность водителей и пассажиров после взлётов и паданий только в 2015-2017 гг. снизилась до уровня начала 1970-х годов.

Нам не удалось найти прямую причину столь необычного поведения смертности пешеходов и водителей и пассажиров по данным РосБРиС в 1988-1999 гг. Одно из возможных, но исключительно спекулятивных, объяснений - предположение, что в данных РосБРиС за период 1988-1999 гг. перепутаны номера рубрик для «Несчастные случаи, связанные с мототранспортом» (160) и «Автомототранспортный несчастный случай на общественной дороге в результате наезда на пешехода» (161). Если, основываясь на этом предположении, рубрике 160 присвоить значения рубрики 161 и наоборот, то полученный ОКС пешеходов и ОКС водителей и пассажиров (бледно-голубая и бледно-оранжевая 
линии на рисунке 9 соответственно) за период 1988-1998 гг. сопоставимы с соответствующим коэффициентом по данным МBД (рисунок 4) и $\mathrm{HCoD}$ (рисунок 6).

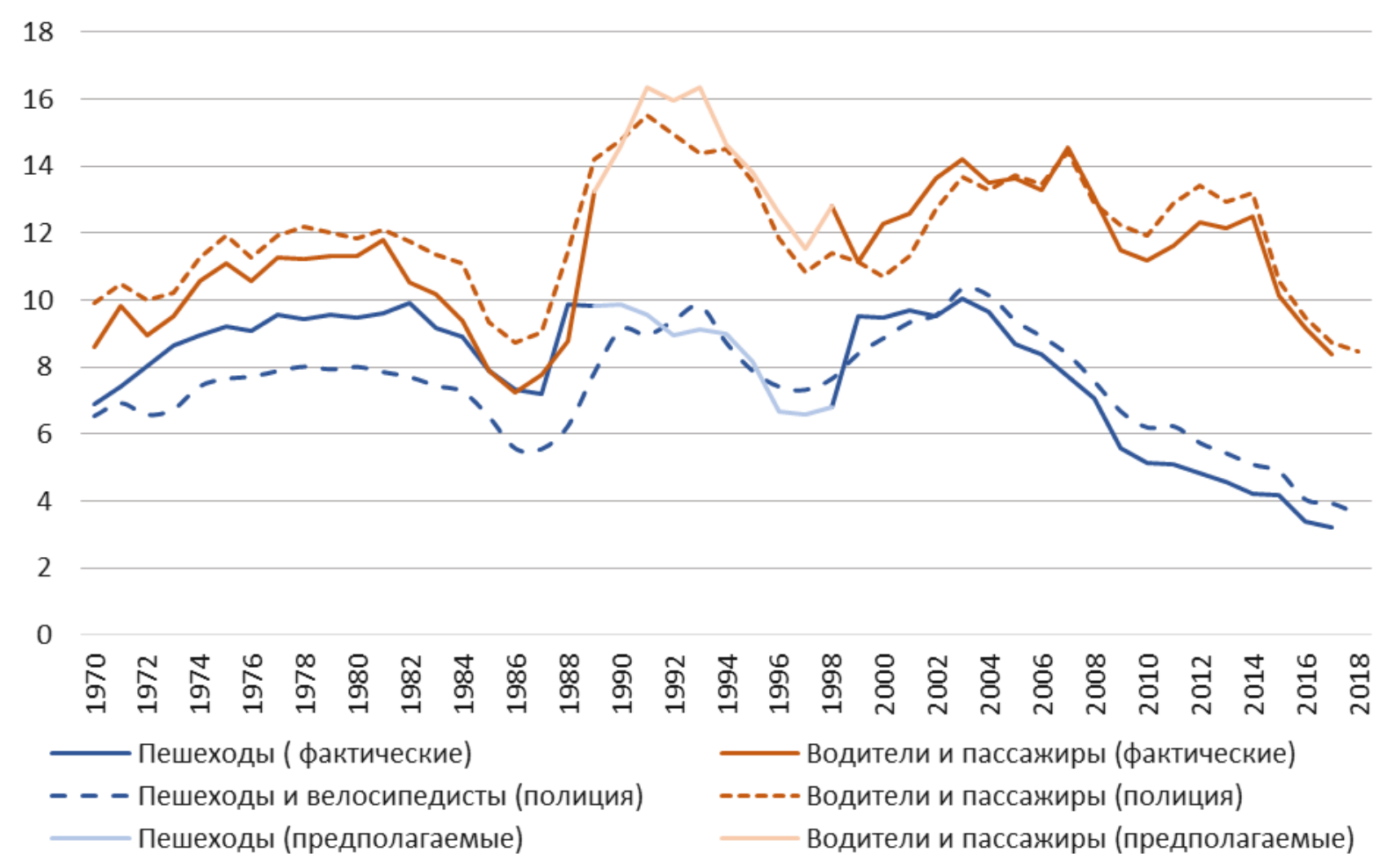

Рисунок 9. Предполагаемые и фактические ОКС участников дорожного движения по данным государственной статистики смертности (сплошные линии) в России

В результате подобной перестановки все поставленные в начале исследования вопросы исчезают. Уровень смертности пешеходов не превышает смертности водителей и пассажиров дорожного движения практически никогда, сравнявшись только в период антиалкогольной кампании 1985 г. Подобное поведение в целом соответствует мировым показателям. Изменения коэффициентов синхронны, а рост смертности водителей и пассажиров после отмены антиалкогольной кампании 1985 г. резкий и существенно выше, чем в конце 1990-х - начале 2000-х годов. Более рискованная форма поведения водителей в СССР в конце 1980-х - начале 1990-х годов отмечалась в системе отчетности МВД.

Так, в СССР в 1989 г. по вине водителей погибло 49,1 тыс. человек, в том числе по вине нетрезвых водителей транспортных средств - 11,6 тыс. человек, тогда как по вине пешеходов - 10,8 тыс. человек, в том числе по вине нетрезвых пешеходов - 2,04 тыс. человек. То есть из всех погибших в 1989 г. в СССР пятая часть погибла по вине нетрезвых участников дорожного движения, но по вине нетрезвых водителей погибло в 5 раз больше человек, чем по вине нетрезвых пешеходов (НИЦ по БДД... 1990). Помимо проблемы нетрезвых водителей, полицией отмечалось, что «в 1989 г. лицами, не имеющими права управления мототранспортными средствами, было совершено 71,8\% всех ДТП, в которых погибло 72,8\% от соответствующих показателей аварийности на индивидуальном транспорте» (НИЦ по БДД... 1990).

Пример Молдавии показывал, что анализировать смертность по агрегированным категориям участников дорожного движения по данным статистики смертности имеет 
смысл только при условии незначительной доли происшествий с неуточненным видом транспорта (код V89). В противном случае структура погибших по категориям участников дорожного движения будет искажена, если этот код не включается ни в одну из определённых категорий участников. Стоит отметить, что высокая доля погибших в ДТП, закодированных кодом V89, характерна не только для Молдавии, но и для таких стран, как США (по данным The WHO Mortality Data Base доля умерших в ДТП, закодированных кодом V89, в 2014 г. составила 32,4\%), Португалия (57\% в 2014 г.), Румыния (69\% в 2015 г.) и Франция (72\% в 2014 г.). Если в источнике данных отсутствует возможность группировки трехзначных кодов причин смерти, код V89 отнесен к агрегированной группе прочих транспортных кодов, а закодированная им доля умерших значительна, то общее число погибших в ДТП, определяемое как сумма погибших только по определённым с точки зрения категорий участников рубрикам (в случае Молдавии №№195 и 196), может быть недооценена.

В России проблема использования неопределённых транспортных кодов причин смерти (V-коды), в том числе V89, также имеет место (Семёнова и др. 2013). Но все же она не столь ярко выражена как в перечисленных выше странах. Так, в 2000 г. доля умерших, закодированных кодом V89, в общем числе погибших в ДТП (коды V02-04, V12-14, V19, V20-79, V82-87, V89) составила 8,1\%, к 2016 г. она снизилась до 4,4\%. Исследование по США показало, что по своим характеристикам неуточненные категории участников погибших в ДТП похожи на защищенных участников дорожного движения (водителей и пассажиров) (Mack et al. 2019). Поэтому в случае России, учитывая немногочисленность этих кодов по числу умерших, мы относили эту категорию к погибшим водителям и пассажирам.

\section{ЗАКЛЮЧЕНИЕ}

В системе отчетности МВД классификация участников дорожного движения не менялась. Её отличительной чертой является отсутствие неопределённой категории участника, т. е. погибший всегда отнесен к одной из чётко определённых категорий. В рамках государственной статистики смертности классификации участников дорожного движения как таковой нет. Она зависит от подхода к агрегации кодов международной классификации болезней (МКБ), ее версии и, что важно в контексте России, версии краткой номенклатуры причин смерти, действующей в рамках той или иной версии МКБ, а также ее русского перевода, их пересмотра.

Поэтому относительно российской динамики смертности участников дорожного движения правомернее доверять данным МВД. Конечно, не для всех стран это утверждение верно. Так, например, в Китае и Индии имеет место недооценка пострадавших пешеходов, в том числе погибших, по опубликованным отчетам полиции (Bhalla et al. 2017; Hu, Ma, Zhou 2012; Li et al. 2016; Singh et al. 2018). Проблема определения категории участника дорожного движения в рамках статистики смертности существует не только в России, но и в США, где проблемной группой являются защищенные участники дорожного движения (Mack et al. 2019). В России же ситуация иная, в основном пешеходы кодируются как попавшие в неуточненный как дорожный или недорожный несчастных случай и в 
результате вообще не попадают в число умерших в ДТП при использовании краткой номенклатуры причин смерти (Пьянкова и др. 2019). Однако этого не происходит при группировке подробных кодов причин смерти в соответствии с международными подходами к выделению погибших в ДТП, как было выполнено в данном исследовании.

Использование данных государственной статистики смертности возможно при необходимости дифференциального анализа дорожно-транспортной смертности по полу, возрасту и типу местности в России. При необходимости выделения категорий участников дорожного движения использовать государственную статистику смертности в России необходимо с осторожностью. На наш взгляд, обоснованно использование следующих открытых источников данных: 1) данные HCoD с 1988 г.; 2) данные РосБРиС с 1970 по 1988 г. и после 1999 г.

Как показали сравнения России с Латвией и Молдавией, подобные сложности в анализе долгосрочных тенденций смертности по категориям участников дорожного движения на основе государственной статистики смертности могут возникать в постсоветских странах, где использовалась советская краткая номенклатура причин смерти. Однако этот вопрос требует дальнейшего изучения.

\section{ЛИТЕРАТУРА}

Вишневский А.Г. (Ред.) (2017). Смертность от внешних причин в России с середины XX века. https://doi.org/10.17323/978-5-7598-1397-2

НИЦ по БДД МВД СССР (n.d.). Дорожно-транспортные происшествия в СССР (Статистический сборник за).

НИЦ по БДД МВД СССР (1990). Дорожно-транспортные происшествия в СССР (19851989 г2.).

Преступность и правонарушения в СССР. Статистический сборник. 1989 (1990).

Пьянкова А.И., Фаттахов Т.А., Баканов К.С., Юрасова Е.Д. (2019). Смертность от дорожно-транспортных происшествий в Москве: анализ связанных данных полиции и государственного статистического учета умерших. Демографическое Обозрение, 6(1), 151-176. https://doi.org/10.17323/demreview.v6i1.9115

Семёнова В.Г., Антонова О.И., Никитина С.Ю., Боровков В.Н., Евдокушина Г.Н. (2013). Проблемы достоверности статистики смертности от транспортных происшествий. Здравоохранение Российской Федеращии, 4, 33-38. URL: http://www.demoscope.ru/weekly/2014/0593/analit01.php

Bhalla K., Khurana N., Bose D., Navaratne K.V., Tiwari G., Mohan D. (2017). Official government statistics of road traffic deaths in India under-represent pedestrians and motorized two-wheeler riders. Injury Prevention, 23(1), 1-7. https://doi.org/10.1136/injuryprev-2016-042053

Charters K.E., Gabbe B.J., Mitra B. (2017). Population incidence of pedestrian traffic injury in high-income countries: A systematic review. Injury, 48(7), 1331-1338.

https://doi.org/10.1016/j.injury.2017.05.021 
Danilova I., Shkolnikov V.M., Jdanov D.A., Meslé F., Vallin J. (2016). Identifying potential differences in cause-of-death coding practices across Russian regions. Population Health Metrics, 14(1). https://doi.org/10.1186/s12963-016-0078-0

Eid H.O., Abu-Zidan F.M. (2015). Pedestrian injuries-related deaths: A global evaluation. World Journal of Surgery, 39(3), 776-781. https://doi.org/10.1007/s00268-014-2853-z

Hu G., Ma S., Zhou M. (2012). Hidden increasing pedestrian fatality between 2006 and 2010 in China: findings from non-police-reported data. Injury Prevention, 18 (Suppl 1), A220.3A221. https://doi.org/10.1136/injuryprev-2012-040590v.7

Li Q., He H., Liang H., Bishai D.M., Hyder A.A. (2016). One outcome, many trends: Understanding national data sources for road traffic fatalities in China. American Journal of Public Health, 106(10), 1793-1795. https://doi.org/10.2105/AJPH.2016.303287

Mack K.A., Hedegaard H., Ballesteros M.F., Warner M., Eames J., Sauber-Schatz, E. (2019). The need to improve information on road user type in National Vital Statistics System mortality data. Traffic Injury Prevention, 20(3), 276-281. https://doi.org/10.1080/15389588.2019.1576036

Mesle F., Shkolnikov V., Hertrich V., Vallin J. (1996). Recent trends in mortality by causes of death in Russia during 1965-1994 [In French and Russian]. http://www.demoscope.ru/weekly/knigi/shkol/shkol.html

Naci H., Chisholm D., Baker, T.D. (2009). Distribution of road traffic deaths by road user group: A global comparison. In Injury Prevention (Vol. 15, Issue 1, pp. 55-59). BMJ Publishing Group Ltd. https://doi.org/10.1136/ip.2008.018721

Pyankova A.I., Fattakhov T.A. (2020). Road traffic mortality in Russia: definitions, trends and perspectives. Demographic Review, 6(5), 120-140. https://doi.org/10.17323/demreview.v6i5.11463

Sengoelge M., Laflamme L., El-Khatib Z. (2018). Ecological study of road traffic injuries in the eastern Mediterranean region: Country economic level, road user category and gender perspectives. BMC Public Health, 18(1). https://doi.org/10.1186/s12889-018-5150-1

Singh P., Lakshmi P.V. M., Prinja S., Khanduja P. (2018). Under-reporting of road traffic accidents in traffic police records- a cross sectional study from North India. International Journal Of Community Medicine And Public Health, 5(2), 579. https://doi.org/10.18203/2394-6040.ijcmph20180232

UNECE Statistical Database (2020). Persons Killed or Injured in Road Traffic Accidents by Category of User. https://w3.unece.org/PXWeb2015/pxweb/en/STAT/STAT_40TRTRANS_01-TRACCIDENTS/09_en_TRAccKTGory_r.px/

World Health Organization (2018). Global status report on road safety 2018.

Yasin Y.J., Grivna M., Abu-Zidan F.M. (2020). Reduction of pedestrian death rates: a missed global target. World Journal of Emergency Surgery, 15, 35. https://doi.org/10.1186/s13017020-00315-2 


\title{
PEDESTRIAN MORTALITY IN RUSSIA: A CONTINUOUS DECLINE OVER THE LAST 25 YEARS?
}

\author{
ANASTASIYA PYANKOVA, TimUR FATTAKHOV
}

\begin{abstract}
Using different data sources (HCoD, IRTAD, UNECE statistical database, police data), our research shows that the significant excess of pedestrian mortality over vehicle occupant mortality in 1988-1999 in Russia according to RusFMD is an abnormal phenomenon that most likely never occurred. Thus, in order to assess levels of mortality by road user types, it is preferable to use police data, according to which, in Russia, pedestrian mortality almost never exceeds that of vehicle occupants. The steady decline in pedestrian mortality began in 2003, not in 1993, as vital statistics show. In 2008, the crude death rate of pedestrians reached the minimum value of the Soviet period. Car occupant mortality, after significant fluctuations, dropped to the level of the early 1970s only in 2015-2017. The use of vital statistics is possible if it is necessary to differentiate road traffic mortality by sex, age, and type of settlements. Categorization by road user types should be done with caution, using the following data sources: HCoD data from 1988 and RusFMD data from 1970 to 1988 and after 1999. It is suggested that difficulties in analyzing long-term mortality by category of road users based on vital statistics may occur in post-Soviet countries, where the Soviet abridged classification of causes of death was used. The prevalence of death coded by unspecified V-codes should also be considered.
\end{abstract}

Key words: pedestrians, car occupants, road users, road traffic mortality, vital statistics, police data.

Anastasiya Pyankova (apyankova@hse.ru), National Research University Higher School of Economics, RUSSIA.

Timur Fattakhov (tfattahov@hse.ru), NATional Research University Higher School of Economics, Russia.

THE STUDY WAS IMPLEMENTED UNDER THE GRANT FROM RUSSIA FOUNDATION FOR BASIC RESEARCH №19-013-00060

DATE RECEIVED : SEPTEMBER 2020.

\section{REFERENCES}

Bhalla K., Khurana N., Bose D., Navaratne K.V., Tiwari G., Mohan D. (2017). Official government statistics of road traffic deaths in India under-represent pedestrians and motorized two-wheeler riders. Injury Prevention, 23(1), 1-7.

https://doi.org/10.1136/injuryprev-2016-042053

Charters K.E., Gabbe B.J., Mitra B. (2017). Population incidence of pedestrian traffic injury in high-income countries: A systematic review. Injury, 48(7), 1331-1338. https://doi.org/10.1016/j.injury.2017.05.021

Danilova I., Shkolnikov V.M., Jdanov D.A., Meslé F., Vallin J. (2016). Identifying potential differences in cause-of-death coding practices across Russian regions. Population Health Metrics, 14(1). https://doi.org/10.1186/s12963-016-0078-0

Eid H.O., Abu-Zidan F.M. (2015). Pedestrian injuries-related deaths: A global evaluation. World Journal of Surgery, 39(3), 776-781. https://doi.org/10.1007/s00268-014-2853-z

Hu G., Ma S., Zhou M. (2012). Hidden increasing pedestrian fatality between 2006 and 2010 in China: findings from non-police-reported data. Injury Prevention, 18 (Suppl 1), A220.3A221. https://doi.org/10.1136/injuryprev-2012-040590v.7 
Li Q., He H., Liang H., Bishai D.M., Hyder, A.A. (2016). One outcome, many trends: Understanding national data sources for road traffic fatalities in China. American Journal of Public Health, 106(10), 1793-1795. https://doi.org/10.2105/AJPH.2016.303287

Mack K.A., Hedegaard H., Ballesteros M.F., Warner M., Eames J., Sauber-Schatz E. (2019). The need to improve information on road user type in National Vital Statistics System mortality data. Traffic Injury Prevention, 20(3), 276-281. https://doi.org/10.1080/15389588.2019.1576036

Mesle F., Shkolnikov V., Hertrich V., Vallin J. (1996). Recent trends in mortality by causes of death in Russia during 1965-1994 [In French and Russian]. http://www.demoscope.ru/weekly/knigi/shkol/shkol.html

Naci H., Chisholm D., Baker, T.D. (2009). Distribution of road traffic deaths by road user group: A global comparison. In Injury Prevention (Vol. 15, Issue 1, pp. 55-59). BMJ Publishing Group Ltd. https://doi.org/10.1136/ip.2008.018721

NITS po BDD MVD SSSR. Dorozhno-transportnyye proisshestviya v SSSR (Statisticheskiy sbornik za 1970-1989). (in Russ).

NITS po BDD MVD SSSR (1990). Dorozhno-transportnyye proisshestviya v SSSR (1985-1989 gg.). (in Russ).

Prestupnost' i pravonarusheniya v SSSR. Statisticheskiy sbornik.1989 (1990). (in Russ).

Pyankova A.I., Fattakhov T.A. (2020). Road traffic mortality in Russia: definitions, trends and perspectives. Demographic Review, 6(5), 120-140. https://doi.org/10.17323/demreview.v6i5.11463

Pyankova A.I., Fattakhov T.A., Bakanov K.S., Yurasova E.D. (2019). Road traffic mortality in Moscow: record linkage study using police data and vital statistics. Demographic Review, 6(1), 151-176. https://doi.org/10.17323/demreview.v6i1.9115

Semenova V.G, Antonova O.I., Nikitina S.Yu., Borovkov V.N., Yevdokushkina G.N. (2013). The issues of reliability of mortality statistics due to traffic accidents. Zdravookhranenie Rossiiskoi Federatsii [Health care of the Russian Federation], 4, 33-37 (in Russ). Retrieved from http://www.demoscope.ru/weekly/2014/0593/analit01.php

Sengoelge M., Laflamme L., El-Khatib Z. (2018). Ecological study of road traffic injuries in the eastern Mediterranean region: Country economic level, road user category and gender perspectives. BMC Public Health, 18(1). https://doi.org/10.1186/s12889-018-5150-1

Singh P., Lakshmi P.V. M., Prinja S., Khanduja P. (2018). Under-reporting of road traffic accidents in traffic police records- a cross sectional study from North India. International Journal Of Community Medicine And Public Health, 5(2), 579. https://doi.org/10.18203/2394-6040.ijcmph20180232

UNECE Statistical Database (2020). Persons Killed or Injured in Road Traffic Accidents by Category of User. https://w3.unece.org/PXWeb2015/pxweb/en/STAT/STAT_40TRTRANS_01-TRACCIDENTS/09_en_TRAccKTGory_r.px/

Vishnevsky A.G. (Ed.) (2017). Mortality from external causes in Russia since the mid-20th century. Moscow: HSE Publishing House (in Russ.) https://doi.org/10.17323/978-5-7598$1397-2$

World Health Organization. (2018). Global status report on road safety 2018. 
Yasin Y.J., Grivna M., Abu-Zidan F.M. (2020). Reduction of pedestrian death rates: a missed global target. World Journal of Emergency Surgery, 15, 35. https://doi.org/10.1186/s13017020-00315-2 